\title{
Therapeutic considerations for mating-induced endometritis
}

\author{
M. H. T. Troedsson \\ Department of Clinical and Population Sciences, College of Veterinary Medicine, University of Minnesota
}

\begin{abstract}
Summary
A transient mating-induced endometritis is most likely physiological in the mare, serving to remove excess spermatozoa, seminal plasma, and contaminants from the uterus. However, the inflammatory reaction has to be resolved and inflammatory products cleared from the uterus prior to embryonal descent into the uterine lumen. Mares that fail to clear a semen-induced inflammation from the uterus develop a persistent mating-induced endometritis which may result in infertility. If susceptibility to persistent mating-induced endometritis is suspected, the mare should be monitored by transrectal ultrasonography for intrauterine fluid accumulation at 6-12 hours intervals after breeding. Treatment should be aimed at assisting the uterus to physically clear contaminants and inflammatory products. Post-mating uterine lavage and/or the use of uterotonic drugs are recommended at 6-12 hours after breeding in mares susceptible to persistent endometritis.
\end{abstract}

keywords: $\quad$ equine, endometritis, treatment

\begin{abstract}
Therapeutische Erwägungen zur equinen Endometritis, hervorgerufen durch die Belegung
Eine transiente, durch die Belegung hervorgerufene Endometritis ist bei der Stute ein physiologisches Ereignis. Sie dient der Eliminierung von Spermien, Seminalplasma und Kontaminationsprodukten aus dem Uterus. Die entzündliche Reaktion muß jedoch beendet und alle Entzündungsprodukte aus dem Uterus entfernt sein, bevor der Konzeptus das Uterusiumen erreicht. Stuten, die nicht in der Lage sind, diesen Reinigungsprozeß zu vollziehen, entwickeln eine persistierende durch die Belegung hervorgerufene Endometritis, mit möglicherweise daraus resultierender Infertilität. Stuten, bei denen eine derartige Endometritisanfälligkeit zu vermuten ist, sollten in 6-12 Stunden Intervallen nach der Belegung ultrasonographisch in Hinblick auf eine intrauterine Flüssigkeitsansammlung überprüft werden. Die Behandlung besteht in einer Unterstützung der physiologischen Reinigungsmechanismen: chirurgische Korrektur von Defekten des äußeren Genitale, gezielte antibakterielle/antimykotische Behandlung, Minimierung der Kontamination durch möglichst präzise Terminierung der Ovulation und Reduzierung der Belegungen auf eine pro Zyklus. Zusätzlich sollte eine Uteruslavage 6-12 Stunden nach der Belegung möglicherweise in Kombination mit Oxytocin durchgeführt werden.
\end{abstract}

Schlüsselwörter: Pferd, Endometritis, Behandlung

\section{Introduction}

Endometritis is a major cause of subfertility in the mare and has a significant economic impact on the equine industry (Dimmock 1939; Collins, 1964; Bain, 1966; Hughes et al., 1966; Ricketts 1975; Gordon and Sartin, 1978; Kenney, 1978; Doig et al., 1981; de la Conch-Bermejillo and Kennedy, 1982; Traub-Dargatz et al., 1991). Based on the current understanding of its etiology and pathophysiology, endometritis should be considered as a multifactorial disease with at least four different causes: (1) sexually transmitted diseases, (2) chronic infectious endometritis, (3) persisting mating-induced endometritis, and (4) endometrosis (chronic degenerative endometritis). Sexually transmitted diseases and chronic infectious endometritis are often diagnosed first after the invading microorganism already has adhered to the endometrial epithelium and started its replication in the uterus. Similar to infectious diseases in other organ systems, infections in the female reproductive tract (sexually transmitted endometritis and chronic infectious endometritis) are most effectively treated with an appropriate anti- microbial. In contrast to infectious endometritis, matinginduced endometritis has a known starting point and treatment can therefore, be initiated before the infection or inflammation has established itself in the endometrium. This report will review the therapeutic aspects and pathophysiology (as it relates to therapy) of mating-induced endometritis.

\section{Pathophysiology of mating-induced endometritis}

Regardless of if mares are bred by natural service or by artificial insemination, semen is deposited directly into the uterus. This provides an excellent opportunity for uterine contamination with bacteria. In addition, recent reports have shown that spermatozoa without bacterial contamination induce an uterine inflammatory response (Kotilainen et al., 1994; Troedsson, 1995; Troedsson et al., 1995a). Rather than considering a transient post-mating endometritis as a pathological condition, mating-induced endometritis is 
likely to be a physiological reaction that serve to remove ex cess spermatozoa, seminal plasma, and possible bacterial contamination from the uterus before the embryo descends into the uterine lumen. However, the uterus must be capable of clearing the inflammation within a few days after breeding/conception in order for a pregnancy to develop normally. Natural resistance to experimentally induced persistent uterine infections was demonstrated by Hughes and Loy (1969). Others found that bacterial infusions with Streptococcus zooepidemicus or Pseudomonas organisms more often resulted in persistent uterine infection in multiparous and barren mares compared to nulliparous mares (Peterson et al., 1969). Based on these studies, mares have been classified as either susceptible or resistant to persistent or chronic endometritis. Mares that are susceptible to persistent bacterial endometritis are likely to be susceptible to persistent mating-induced endometritis (Troedsson, 1997). Local components of the uterine defense mechanisms are responsible for the rapid clearance of an infection or mating-induced inflammation in mares with normal resistance to persistent endometritis (Fig. 1; Watson, 1988; Troedsson, 1994).

Uterine defense mechanisms: Polymorphonuclear neutrophils (PMNs) are present in the uterine lumen within $30 \mathrm{~min}-$ utes after mating (Katila, 1995). Both bacteria and spermatozoa stimulate PMN-chemotaxis into the uterus (Blue et al., 1984; Pycock and Allen, 1988; Troedsson et al., 1993a; Troedsson et al., 1995a). Several mediators, including



Fig. 1: Uterine response to semen and bacterial contamination during breeding. Dysfunctional uterine contractions in response to inflammation in mares susceptible to persistent endometritis result in an impaired uterine clearance. Treatments that assist the uterus to physically clear contaminants and inflammatory products may enhance fertility in affected mares.

Die Reaktion des Uterus auf Samen und bakterielle Kontamination nach der Bedeckung. Bei endometritisanfälligen Stuten resultiert eine gestörte uterine Clearance aus einer insuffizienten uterinen Kontraktion als Antwort auf die Entzündung. Behandlungen, die die physikalische Reinigung von Kontaminationen und Entzündungsprodukten unterstützen, können die Fertilität der betroffenen Stuten erhöhen.
$\mathrm{PGF}_{2} \alpha$ are released during the course of the inflammation (Schalm, 1986). In addition to being an inflammatory mediator, PGF2 $\alpha$ causes myometrial contractions. It has been suggested that $\mathrm{PGF}_{2} \alpha$-induced myometrial contractions are responsible for the rapid mechanical clearance of inflammatory products from the uterus (Troedsson, 1995). Mares that fail to clear a mating-induced inflammation from the uterus develop a persistent endometritis. An impaired physical clearance has been demonstrated in mares with increased susceptibility to persistent endometritis (Evans et al., 1987; Allen and Pycock, 1988; Troedsson and Liu, 1991; LeBlanc et al., 1994a). It has also been shown that delayed uterine clearance in these mares is due to an impaired myometrial activity in response to inflammation (Troedsson et al., 1993b). In contrast to the transient post mating endometritis, persistent mating-induced endometritis has severe consequences for the fertility of affected mares. A persistent inflammation often results in premature luteolysis and embryonic loss in response to increased $\mathrm{PGF}_{2} \boldsymbol{\alpha}$ concentrations. The inflammation could also interfere directly with the survival of an embryo (Smith et al., 1971; Waites and Bell, 1982, Hever et al., 1993). Proteolytic enzymes, oxygen radicals and other toxic products are released during PMN-phagocytosis. These products must be eliminated from the uterus in a timely fashion in order to allow embryonic survival when the embryo descends into the uterus.

\section{Clinical signs of persistent mating-induced endometritis}

Clinically, mares with mating-induced endometritis accumulate fluid within the uterine lumen following breeding. Merocrine endometrial secretion and edema is normal during estrus (Tunon et al., 1995), but the secretion should be effectively drained via lymphatics and the cervix. Both these draining mechanisms are dependent on functional myometrial contractions (Guyton, 1991). LeBlanc et al. (1995) observed that mares with delayed uterine clearance had dysfunctional lymphatic clearance. In addition, mares that fail to relax the cervix during estrus are likely to develop a persistent endometritis after mating. A diagnostic technique, using scintigraphy to monitor uterine clearance has been developed to identify mares with delayed uterine clearance (LeBlanc et al. 1994a). It was concluded that in order for a mare to be considered normal, $>50 \%$ of inoculated radiocolloids need to be cleared from the uterus within 2 hours of the inoculation. Unfortunately, scintigraphy is not readily available in all brood mare practices, and many mares that develop a persistent endometritis after mating are free of uterine inflammation prior to mating. It may therefore, be difficult to identify susceptible mares before they have been bred. The presence of free intraluminal fluid prior to breeding strongly suggests susceptibility to persistent endometritis (Pycock and Newcombe, 1996). Furthermore, a detailed breeding history and a careful reproductive examination prior to breeding may reveal predisposing conditions. A mare with a history of chronic infectious endometritis is 
likely to develop persistent mating-induced endometritis. A correlation between severe pathological findings on a uterine biopsy and susceptibility to persistent endometritis has been reported (Troedsson et al., 1993c). Mares with delayed uterine clearance often suffer from visceroptosis with a significant forward tilt of the uterus when it expands over the brim of the pelvis (LeBlanc, personal communication). This may also contribute to accumulation of fluid and inflammatory products following mating. If susceptibility to persistent mating-induced endometritis is suspected, the mare should be closely monitored by transrectal ultrasonography for intrauterine fluid accumulation at 6-12 hours intervals after breeding. Normal mares may retain fluid in the uterine lumen up to 6 hours after mating. However, if intrauterine fluid is present at 12 hours or more after mating, the mare should be considered to have a persistent mating-induced endometritis.

\section{Treatment of mares with persistent mating-induced endometritis}

Treatment of mares that are susceptible to persistent mating-induced endometritis should be aimed at assisting the uterus to physically clear contaminants and inflammatory products (Fig 1). Before breeding a mare that is susceptible to persistent post-mating endometritis, the reproductive tract has to be free from predisposing factors and infection. This can be achieved by surgical corrections of defective external genital barriers and an effective treatment of existing bacterial or fungal endometritis. The uterus should be confirmed free from infection, based on cytology and culture before the mare is bred. Susceptible mares should, if possible be bred no more than once per cycle as close to ovulation as possible. Large-volume uterine lavage at 6 to 12 hours after mating will effectively aid the mare to clear inflammatory products from the uterus without interfering with conception (Brinsko et al., 1991; Troedsson et al., 1995b). Following thorough cleansing of the perineum, a uterine flushing catheter (30 French, $80 \mathrm{~cm}$ long, with a $75 \mathrm{ml}$ balloon cuff $^{1}$ ) should be introduced through the cervix. Once the cuff is located in the uterus, it will be inflated until it effectively seals the internal cervical os. A total of $1 \mathrm{li}-$ ter of buffered saline solution or lactated ringer solution should be infused into the uterus. Following brief transrectal massage of the uterus to ensure an even distribution of fluid in both horns, the fluid should be recovered in a bottle that allows visual examination. The lavage should be repeated until the recovered fluid is clear. A cloudy fluid is indicative of inflammatory debris. Measurement of the recovered fluid or ultrasonographic examination of the uterus will ensure that all fluid has been recovered. This is important, since the mare has an impaired ability to spontaneously clear the uterus. Uterine lavage should be performed after each mating to be effective.

\footnotetext{
1 Bivona Inc. Gary, IN.
}

The use of uterotonic drugs that stimulate myometrial contractions can also assist in the clearance of inflammatory fluid from the uterus. The administration of oxytocin $(20 \mathrm{U}$ $\mathrm{IM}$ ) at 4 to 8 hours after mating has been shown to effectively clear the uterus, resulting in improved pregnancy rates in susceptible mares (LeBlanc et al., 1994b; LeBlanc 1994; Pycock, 1994, Rasch et al., 1996). Prostaglandins have also been demonstrated to increase myometrial activity and assist in clearing the uterine lumen of contaminating products (Troedsson et al., 1995b; Troedsson et al., 1995c). Studies of the duration of myometrial activity following administration of oxytocin and PGF $2 \alpha$ show that $20 \mathrm{U}$ of oxytocin causes 1 hour of increased myometrial activity, and that $10 \mathrm{mg}$ of PGF $2 \alpha$ causes 5 hours of increased activity (Troedsson et al., 1995c). However, both drugs also affected the oviductal smooth muscles in a similar way. Considerations of the duration of the effect of oxytocin and prostaglandins on both myometrial and oviductal activity should be made before these hormones are used in postmating treatments. In a recent report, the investigators found that oxytocin was more effective than prostaglandins in clearing the uterus from radiocolloids (Combs et al., 1996). Results from the study suggested that cloprostenol was more effective than $\mathrm{PGF}_{2} \alpha$ and fenprostalene. However, susceptible mares responded to all uterotonins with increased clearance of radiocolloids. It appears that the efficacy and safety aspects favor oxytocin over prostaglandins in most cases. A combination of post-mating uterine lavage and oxytocin treatment is preferred by some practitioners.

Post-mating infusion with antibiotics has been used in the management of mares with persistent mating-induced endometritis (Asbury and Lyle, 1993). Although spermatozoa, rather than bacteria have been implicated as the cause of mating-induced endometritis, it was recently suggested that seminal plasma suppresses both chemotaxis and phagocytosis of equine PMNs (Scheytt and Gilbert, 1995; Troedsson et al., 1995a). An initial suppressive effect of seminal plasma on PMN function may predispose the mare to develop a bacterial uterine infection after mating since semen often is contaminated with a variety of potentially pathogen microorganisms (Kenney et al., 1975). Treatment of susceptible mares with either intrauterine saline lavage, PGF $\alpha$, or penicillin at 12 hours after an intrauterine infusion of Streptococcus zooepidemicus showed that saline lavage and $\mathrm{PGF}_{2} \alpha$ were equally effective to eliminate bacteria from the uterus as penicillin treatments (Troedsson et al., 1995b). These results suggest that antibiotics may not be necessary, even in cases of bacterial contamination, if mares are treated with uterine lavage or uterotonins within 12 hours after mating.

In conclusion, obtaining a current breeding history and the performance of an accurate reproductive examination prior to breeding is necessary to identify individual mares that are likely to develop persistent mating-induced endometritis. Once mares are identified to be at risk of persistent endometritis following mating, ultrasonographic monitoring of intrauterine fluid accumulation and treatments that aid in uterine clearance should be employed. A rapid uterine 
clearance following mating is necessary in preventing a persistent inflammation. Uterine lavage and/or oxytocin treatments are recommended between 6 and 12 hours after breeding. It must be emphasized that the majority of mares that develop a transient inflammation after mating, are fully capable of an effective uterine clearance without any assistance. Only mares with delayed uterine clearance should be treated.

\section{References}

Allen, W. E. and Pycock, J.F. (1988): Cyclical accumulation of uterine fluid in mares with lowered resistance to endometritis. Vet. Rec. 122, 489-490.

Asbury, A. C. and Lyle, S. K. (1993): Infectious causes of infertility. In: Equine Reproduction, AO McKinnon and $J L$ Voss (eds), Philadelphia, Lea \& Febiger, pp 381-391.

Bain, A.M. (1966): The role of infertility in the Thoroughbred mare. Vet. Rec $78,168-173$
Blue, H. B., Blue, M. G., Kenney, R. M., and Merrit, T. L. (1984): Chemotactic properties and protein of equine uterine fluid. Am. J. Vet. Res. 45, 1205-1208.

Brinsko, S. P., Varner, D. D., and Blanchard, T. L. (1991): The effect of uterine lavage performed four hours post-insemination on pregnancy rates in mares. Theriogenology 35, 1111-1191.

Collins, S.M. (1964): A study of the incidence of cervical and uterine infection in Thoroughbred mares in Ireland. Vet. Rec. 76, 673-675.

Combs, G. B., LeBlanc, M.M., Neuwirth, L. and Tran, T.Q. (1996): Effects of prostaglandin $F_{2} \alpha$, cloprostenol and fenprostalene on uterine clearance of radiocolloid in the mare. Theriogenology 45 , 1449-1455.

Dimmock, W. (1939): Equine breeding hygiene. J. Am. Vet. Med. Assoc. 94, 469-478.

Doig, P. A., MCNight, J. D. and Miller, R. B.I. (1981): The use of endometrial biopsy in the infertile mare. Can. Vet. J. 22, 72-76.

De la Concha-Bermejillo, A. and Kennedy, P. C. (1982): Prognostic value of endometrial biopsy in the mare: A retrospective analysis. $J$ Am. Vet. Med. Assoc. 181, 680-681.

Evans, M. J., Hamer, J.M., Gason, L.M. and Irwirne, C. G. H. (1987): Factors affecting uterine clearance on inoculated materials. J. Reprod. Fert. 35 (Suppi), 327-334

\section{Tagung über Labordiagnostik}

\section{Kurs über Entnahme und Bearbeitung von Muskelbiopsien beim Pferd Arbeitsgruppe Pferd und Abbott Diagnostika}

\section{5.-26. Oktober 1997, Bonn}

Tagung am 25. Oktober, 9.00-18.30 Uhr

- Desmond Leadon (Irland): Bedeutung hämatologischer Variablen für die Diagnose von Krankheiten beim Sportpferd

- Arne Lindholm (Schweden): Polycitämie als Ursache mangelhafter Leistung des Rennpferdes

- Desmond Leadon: Einsatz der Labordiagnostik vom Jährling bis zum Rennpferd zur Beurteilung der Leistungsfähigkeit

- Hans-Peter Sallmann (Hannover): Bedeutung des oxidativen Stresses von Pferden durch körperliche Belastung und Fütterung

- Peter Bauer (Neuruppin): Muskelbioptische Untersuchungen bei Mensch und Pferd -

Programm:

Teilnahmegebühr: DM 200,- für die Tagung (inkl. MwSt, Tagungsband und Kaffeepausen), DM 400,- für den Kurs (begrenzte Teilnehmerzahl)

Anmeldung: $\quad$ schriftlich unter Beifügung eines Verrechnungsschecks an Dr. Arno Lindner, Im Eichholz 10, 53127 Bonn

Information: Telefon (02 28) 299259, Fax (02 28) 284761 , E-Mail <arnolindnerbonn@t-online.de>

ATF-Anerkennung: 12 Stunden 
Gordon, L. R. and Sartin, E.M. (1978): Endometrial biopsy as an aid to diagnosis and prognosis in equine fertility. J. Equine Med. Surg. 2, 328-336

Guyton, A. C. (1991): The lymphatic system. In: Textbook of medical physiology, 8th ed. W.B. Saunders Co. Philadelphia, PA. pp 180-184.

Hever, J. A., King. S. S., Gardiner, C. S., Ferriera-Diaz, G. and Nequin, L. G. (1993): Uterine secretions from different endometrial classifications affect viability of early murine embryos cultured in vitro. $\mathrm{J}$. Eq. Vet. Sci. 13, 494-497.

Hughes, J.P., Asbury, A. C., and Burd, H.E. (1966): The occurrence of Pseudomonas in the reproductive tract of mares and its effect on fertility. Cornell Vet. 56, 595-610.

Hughes, J.P. and Loy, R. G. (1969): Investigations on the effect on intrauterine inoculation of Streptococcus zooepidemicus in the mare. Proc. Am. Assoc. Eq. Pract. 15, 289-292.

Katila, T. (1995): Onset and duration of uterine inflammatory response of mares after insemination with fresh semen. Biol. Reprod. Mono 1: Equine Reprod. 4, 515-517.

Kenney, R. M. (1978): Cyclic and pathologic changes of the mare endometrium as detected by biopsy, with a note on early embryonic death. J. Am. Vet. Med, Assoc. 172, 241-262.

Kenney, R. M., Bergman, R. V., Cooper, W. L. and Morse, G. W. (1975): Minimal contamination techniques for breeding mares: Techniques and preliminary findings. Proc. Am. Assoc. Eq. Pract. 27, 327-336.

Kotilainen, T., Huhtinen, M. and Katila. T. (1994): Sperm induced leukocytosis in the equine uterus. Theriogenology 41, 629-636.

LeBlanc, M.M. (1994): Oxytocin - the new wonder drug for treatment of endometritis? Eq. Vet. Educ. 6, 39-43.

LeBlanc, M.M., Neuwirth, L., Asbury, A.C., Tran, T., Mauragis, D. and Klapstein, E. (1994a): Scintigraphic measurement of uterine clearance in normal mares and mares with recurrent endometritis. Eq. Vet. J. 26, 109-113.

LeBlanc, M. M. Neuwirth, L., Mauragis, D., Klapstein, E. and Tran, T. (1994b): Oxytocin enhances clearance of radiocolioid from the uterine lumen of reproductively normal and infertile mares. Eq. Vet. J. 26, 279-282

LeBlanc, M. M., Johnson, R. D., Calderwood Mays, M. B. and Valderrama, C. (1995): Lymphatic clearance of india ink in reproductively normal mares and mares susceptible to endometritis. Biol. Reprod. Mono 1, 501-506.

Peterson, F. B., MCFeely, R. A. and David, J. S. E. (1969): Studies on the pathogenesis of endometritis in the mare. Proc. Am. Assoc. Eq. Pract. 15, 278-285.

Pycock, J.F. and Allen, W. E. (1988): Pre-chemotactic and chemotactic properties of uterine fluid from mares with experimentally induced endometritis. Vet. Rec. 123, 193-195.

Pycock, J.F. (1994): Assessment of oxytocin and intrauterine antibiotics on intrauterine fluid and pregnancy rates in the mare. Proc. Am. Assoc. Eq. Pract. 40, 19-20.

Pycock, J.F. and Newcombe, J. R. (1996): The relationship between intraluminal uterine fluid, endometritis, and pregnancy rate in the mare. Eq. Pract. 18, 19-22.

Rasch, K., Schoon, H.-A., Sieme, H., and Klug, E. (1996): Histomorphological endometrial status and influence of oxytocin on the uterine drainage and pregnancy rates in mares. Eq. Vet. J. 28, 455-460.

Ricketts, S. W. (1975): Endometrial biopsy as a guide to diagnosis of endometrial pathology in the mare. J. Reprod. Fert. (Suppl) 23, 341-345.

Schalm, O.W. (1986): In: Veterinary hematology 4th ed. Jain, N.C. Lea \& Febiger, Philadelphia, PA. 712-714.

Scheytt, A.F. and Gilbert, R. O. (1995): Stallion seminal plasma as a factor in the pathogenesis of equine endometritis. Proc. Society for Theriogenology 306 (abstr).
Smith, D. M., El Sahwi, S., Wilson, N. and Moyer, D. L. (1971): Effects of polymorphonuclear lymphocytes on the development of mouse embryos cultured from two-cell stage to blastocysts. Biol. Reprod. 4, 74-83.

Traub-Dargatz, J.L., Salman, M.D. and Voss, J.L. (1991): Medical problems of adult horses, as ranked by equine practitioners. J. Am. Vet. Med. Assoc. 198, 1745-1747.

Troedsson, M. H.T. (1994): Uterine defense mechanisms in the mare. Arch. STD/HIV Res. 8, 259-270.

Troedsson, M.H.T. (1995): Uterine response to semen deposition in the mare. Proc. Society for Theriogenology 130-135.

Troedsson, M. H. T. (1997): Diseases of the uterus. In: Current therapy in equine medicine 4, ed. E. D. Robinson, W. B. Saunders Co. Philadelphia, PA. pp 517-524.

Troedsson, M. H.T. and LiU, I. K. M. (1991): Uterine clearance of nonantigenic markers $\left({ }^{51} \mathrm{Cr}\right)$ in response to a bacterial challenge in mares potentially susceptible and resistant to chronic uterine infec. tion. J. Reprod. Fert. (Suppl) 44, 283-288.

Troedsson, M. H. T. Liu, I. K. M. and Thurmond, M. (1993a): Function of uterine and blood derived polymorphonuclear neutrophils (PMN) in mares susceptible and resistant to chronic uterine infection (CUI): phagocytosis and chemotaxis. Biol. Reprod. 49, 507-514.

Troedsson, M.H. T., Liu, I. K. M., Ing, M., Pascoe, J. and Thurmond, M. (1993b): Multiple site electromyography recordings of uterine activity following an intrauterine bacterial challenge in mares susceptible and resistant to chronic uterine infection. J. Reprod. Fert. 99. 307-313.

Troedsson, M.H.T., deMoraes, M. J., and Liu, I. K.M. (1993c): Correlations between histologic endometrial lesions in mares and clinical response to intrauterine exposure to Streptococcus zooepidemicus. Am. J. Vet. Res. 54, 570-572

Troedsson, M.H.T., Steiger, B.N., Ibrahim, N.M., Foster, D. N. and Crabo, B. G. (1995a): Mechanism of sperm-induced endometritis in the mare. Biol. Reprod. (Suppl) 52, 307.

Troedsson, M.H.T., Scott, M.A. and Liu, I.K.M. (1995b): Comparative treatment of mares susceptible to chronic uterine infection. Am. J. Vet. Res. 56, 468-472.

Troedsson, M.H. T., Liu, I. K. M., Ing, M. and Pascoe, J. (1995c): Smooth muscle electrical activity in the oviduct, and the effect of oxytocin, prostaglandin $F_{2} \alpha$, and prostaglandin $E_{2}$ on the myometrium and the oviduct of the cycling mare. Biol. Reprod. Mono 1. 475-488.

Tunon, A. M., Rodriguez-Martinez, H., Haglund, A., Albihn, A., Magnusson, U. and Einarsson, S. (1995): Ultrastructure of the secretory endometrium during oestrus in young maiden and foaled mares. Eq. Vet. J. 27, 382-388.

Waites, G. T. and Bell. S. C. (1982): Glycogen-induced intrauterine leucocytosis and its effect on mouse blastocysts implantation in vivo and in vitro. J. Reprod. Fert. 66, 563-569.

Watson, E.D. (1988): Uterine defense mechanisms in mares resistant and susceptible to persistent endometritis: A review. Eq. Vet. J. 20 , $397-400$.

Mats H. T. Troedsson, DVM, PhD

Department of Clinical and Population Sciences

College of Veterinary Medicine

University of Minnesota. St.Paul, MN 55108

Tel: 001-612-6256733

Fax: 001-612-625 2743

email: troed001@maroon.tc.umn.edu 